\title{
Enhancing Profitability of Ethanol Fermentation through Gamma Ray Mutagenesis of Saccharomyces cerevisiae
}

\author{
Muhammad Arshad ${ }^{1}$, Tariq Hussain ${ }^{1}$, Navida Chaudhry ${ }^{1}$, Halima Sadia ${ }^{2}$, Bilal Aslam ${ }^{3}$, \\ Usman Tahir ${ }^{4}$, Mazhar Abbas ${ }^{1}$, Naseem Qureshi5, Arif Nazir ${ }^{6 *}$, \\ Muhammad Ibrahim Rajoka ${ }^{7}$, Munawar Iqbal ${ }^{6}$ \\ ${ }^{1}$ Jhang-Campus, University of Veterinary and Animal Sciences Lahore, Pakistan \\ ${ }^{2}$ Poultry Research Institute Rawalpindi, Pakistan \\ ${ }^{3}$ Institute of Pharmacy, Physiology and Pharmacology, University of Agriculture Faisalabad Pakistan \\ ${ }^{4}$ Livestock and Dairy Development, Punjab Pakistan \\ ${ }^{5}$ Department of Chemistry, Karakoram International University, Gilgit-Baltistan, Pakistan \\ ${ }^{6}$ Department of Chemistry, The University of Lahore, Lahore-Pakistan \\ ${ }^{7}$ Department of Bioinformatics and Biotechnology, Government College University Faisalabad, Pakistan
}

Received: 24 April 2017

Accepted: 17 October 2017

\begin{abstract}
Invertase has a vital role in ethanol fermentation, especially on sucrose-containing media. In this study, catabolite-resistant mutants of Saccharomyces cerevisiae were isolated through gamma ray mutagenesis with improved productivity of ethanol and invertases. Enzyme productivity of mutant yeast was compared with that of the parent. Various fermentation parameters were optimized, including substrate concentration, $\mathrm{pH}$, and temperature on the production of invertase and ethanol. Applying optimized conditions $\left(\mathrm{pH} 4.6,37^{\circ} \mathrm{C}\right.$ ) at lab scale, industrial scale experiments in $300 \mathrm{~m}^{3}$ fermenters were performed. Mutants had completed fermentation with high efficiency in $28 \mathrm{hrs}$ irrespective of parents that took 36 hrs. The mutant obtained is of great commercial value as it has the potential to enhance the overall profitability of the fermentation process through advancement in the quality of the final product.
\end{abstract}

Keywords: invertase, ethanol, mutagenesis, Saccharomyces cerevisiae, fermentation, enzyme

\section{Introduction}

World energy consumption is growing at rising rates, facing the progressive depletion of its energetic resources based on non-renewable fuels that also lead

*e-mail: anmalik77@gmail.com

to the increase in the generation of polluting gases released into the atmosphere, which have caused changes in the global climate. The solution is to find alternative sources of energy [1]. The use of biomass is an environment friendly way of power generation [2-11]. Ethanol is the main liquid biofuel currently replacing 3\% of gasoline. Worldwide, $>50 \%$ bioethanol is produced from sugarcane juice and molasses. The principal sugar, sucrose, present in the molasses is generally the mostly 
available economical sugar for the industrial utilization of the yeast Saccharomyces cerevisiae [12].

It is commonly believed that yeast cells express an extracellular invertase capable of splitting sucrose into glucose and fructose. Saccharomyces cerevisiae can use different kinds of carbon sources, but the glucose and fructose are ideal for its growth. When these sugars are present in the medium, the production of enzymes required for utilizing other carbon sources is enormously withdrawn or totally blocked. The trend is called carbon catabolite repression [13], altering a number of phenomena in yeast in the central and peripheral metabolism.

Therefore, sugars present in the media are used in an orderly way, creating a lag phase and resulting in prolonged production time [14]. The process will be more proficient by simultaneous use of all the sugars by the deregulated strain through a reduction in production time.

Keeping in view the above-stated problem and industrial need, the Saccharomyces cerevisiae strain presently being used at a distillery was irradiated with gamma rays. 2-Deoxy-D-glucose (DOG) has been widely used to select glucose-derepressed mutant [15-16]. The glucose-deregulated mutants with high invertase activity were selected. The strain's efficiency is dependent on invertase activity to hydrolyze the sucrose even under the inhibitory conditions existing in molasses [17]. Invertase production was optimized on the laboratory scale on industrial complex media (molasses) irrespective of synthetic media that is highly favorable over the conventional complex media. Ethanol fermentation was done in $300 \mathrm{~m}^{3}$ industrial fermenters.

The objective of this work was to characterize and optimize invertase production at laboratory scale and further implement on a large scale. This study is new of its kind to quantify the effect of invertase activity on ethanol production on an industrial scale.

\section{Materials and Methods}

The culture was maintained at yeast culture medium. Molasses with the addition of $\mathrm{N}$ and $\mathrm{P}$ source [18] was used in all the experiments otherwise mentioned. Commercial sulfuric acid was used to adjust $\mathrm{pH}$ [19]. The presently used strain in ethanol production process of Shakarganj Mills Distillery Jhang Pakistan, of SAFInstant France was subjected to gamma ray-irradiated mutagenesis as described by Sridhar and Elliott [20] in three repeats. For preparation of inoculums, well-grown single colonies of each parent and mutant culture were picked up by a loop and inoculated in $100 \mathrm{ml}$ of yeast inoculum medium in an Erlenmeyer flask (sterilized at $121^{\circ} \mathrm{C}$ and $1.5 \mathrm{PSI}$ ) and incubated at $37^{\circ} \mathrm{C}$ in an orbital shaker (Toshiba, Japan) at $120 \mathrm{rpm}$ for $24 \mathrm{hrs}$. Forty-five $\mathrm{ml}$ of molasses medium was transferred to each $250 \mathrm{ml}$ Erlenmeyer flask. The flasks were cotton plugged and autoclaved for $15 \mathrm{~min}$ and cooled at room temperature. Five $\mathrm{ml}$ of inoculum were transferred to each flask under sterile conditions. Flasks were then incubated in an orbital incubator shaker. Various conditions and process variables, temperature, nitrogen, phosphorus source ratios, and $\mathrm{pH}$ were optimized for the maximum production of invertase and ethanol. Concentrations of total fermentable sugars (TFS) in diluted molasses were measured calorimetrically as described earlier [21]. The concentration of TRS in diluted molasses, after sucrose inversion using $\mathrm{HCl}$ and amounts of residual sugars in fermented wash, was measured by the FehlingSoxhlet method. As 10\% TFS were inactivated, this loss was made up by adding firter-sterized glucose to the fermentor. But for large-scale study, this practice was not adopted as fermentation was performed on unsterilized molasses. Ethanol in fermented samples was determined with an ebulliometer and confirmed on GC as described previously [22].

Fermenter studies were carried out in a microprocessor-controlled 23-1 stainless steel fermenter (Biostat C5, Braun Biotechnology, Melsungen, Germany) (15-1 working-volume vessel) equipped with instruments and controllers for parameters such as agitation, temperature, $\mathrm{pH}$, and dissolved oxygen, and fitted with a reflux cooler in the gas exhaust to minimize evaporation. The vessel was filled with mediumcontaining sugars (15\% TRS, found optimum) in molasses supplemented with an optimum concentration of $\left(\mathrm{NH}_{4}\right)_{2} \mathrm{SO}_{4}(7.5 \mathrm{~g} / \mathrm{l})$ and other nutrients. The $\mathrm{pH}$ was adjusted to 4.6 (optimum) and the medium was steam-sterilized in situ for $30 \mathrm{~min}$. The fermenter was inoculated with $10 \%(\mathrm{v} / \mathrm{v})$ active inoculum. The aeration was carried out through a sparger at $15 \mathrm{l} / \mathrm{min}$ for $8 \mathrm{~h}$ to enhance biomass production before switching over to $3 \mathrm{l} / \mathrm{min}$. This process lasted up to $72 \mathrm{~h}$, during which foaming was controlled by adding silicone oil as an antifoaming agent. Substrate, nitrogen source, $\mathrm{pH}$, and temperature-dependent formation of ethanol occurred along with minute quantities of acetic acid, succinic acid, and glycerol. $\mathrm{pH}$ dropped due to the formation of acetic acid, so $\mathrm{pH}$ was controlled automatically at 4.6 using $\mathrm{KOH}$. In all studies, $100 \mathrm{ml}$ samples in triplicate were collected from both parental and mutant cultures after every $8 \mathrm{~h}$ for different analysis periodically.

In $1 \mathrm{ml}$ of the $0.2 \mathrm{M}$ sucrose and $1 \mathrm{ml}$ sodium acetate buffer mixtures, $100 \mu \mathrm{l}$ of appropriately diluted invertase solution was added. The reaction mixture was agitated at $50^{\circ} \mathrm{C}$ for $30 \mathrm{~min}$ in a shaking water bath. Then $50 \mu \mathrm{l}$ reaction mixtures were added to $950 \mu \mathrm{l}$ distilled water and boiled for $10 \mathrm{~min}$ to deactivate the enzyme. The amount of glucose formed was determined using a glucose oxidase kit [21]. Treatment effects were compared by the protected least significant methods with ANOVA-II using MstatC software.

For genetic variability assessment, total genomic DNA from parent and mutant strains (24 h grown cultures) of Saccharomyces cerevisiae were isolated separately using the CTAB (cetyltrimethylammonium bromide) method with little modification. The method is employed for purification of DNA from plant tissues. After RNA 
treatment, the quantity of DNA was measured using a fluorimeter (Hoefer USA), and quality was checked by running $0.8 \mathrm{ng}$ of both parent and mutant strain DNA on agarose gel $(0.8 \%)$. Data attained through the analysis of the primers (RAPD assay amplification by PCR technique) were utilized to assess the genetic similarity based on the number of shared amplification products. The similarity index was approximated through bivariate (1-0) data. $\mathrm{pH}$ determination was done as reported earlier [23]. The quantity of ethanol produced in alcoholic fermentation of molasses was estimated on an ebulliometer. However, it was confirmed on gas chromatography afterwards [22].

\section{Results and Discussion}

Composite mutant was developed through off and on exposure to $\gamma$-rays. Only 8 mutants developed larger pink colour in sucrose-DG medium and the best single mutant in plate tests of the mutant strain $S$. cerevisiae was selected, designated as SML-1. The potential mutant SML-1 was grown several times and streaked until it became stable. Gamma ray-induced mutations are reliable methods for developing mutant derivatives [20]. Finally, a stable mutant was used for further studies in liquid culture. The parent and mutant strains of Saccharomyces cerevisiae were tested in time course studies (Fig. 1) for ethanol production and conditions were optimized at laboratory scale. Initially the effect of TFS on cell mass and ethanol production was tested in a 231 fermentor (working volume 15 1; Fig.1), as mentioned previously. Representative time course of ethanol production by both parental and mutant strains for molasses batch

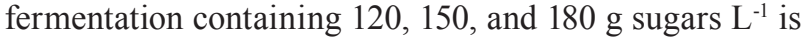
presented in Fig. 1.

Fig. 1 also shows time course of invertase production as well (bottom far right). Time consumed by the mutant derivative was $8 \mathrm{~h}(28 \mathrm{~h})$ less than that taken by the wild strain (36 h). Maximum ethanol $\left(80 \mathrm{~g} \mathrm{~L}^{-1}\right)$ was obtained with mutant derivative (Fig. $1180 \mathrm{~g} / \mathrm{L}$ ). The growth curves (Fig. 1) indicated that cell mass concentration in both strains reached maximum values after 28 and $36 \mathrm{~h}$ in the case of mutant and parental strains, respectively. These curves also indicated that production of ethanol was apparently growth-associated up to $24 \mathrm{~h}$ of fermentation, after which ethanol production was nongrowth associated.

The results of kinetic parameters for substrate consumption and cell mass formation are presented in Table 1. The effect of carbon source concentrations on all growth parameters, namely cell mass formation rate $\left(Q_{x}\right)$, growth yield coefficient $\left(Y_{x / s}\right)$, specific substrate consumption rate $\left(\mathrm{q}_{\mathrm{s}}\right)$, and maximum specific growth rate $\left(\boldsymbol{\mu}_{\mathrm{m}}\right)$. The interactive effect of carbon sources and organisms was found to be highly significant with respect to all growth kinetic parameters. Maximum specific growth rate $\left(\mu_{\mathrm{m}}\right)$, specific substrate uptake rates $\left(\mathrm{q}_{\mathrm{S}}\right)$, and volumetric rate of substrate consumption $\left(Q_{S}\right.$; Table 1)
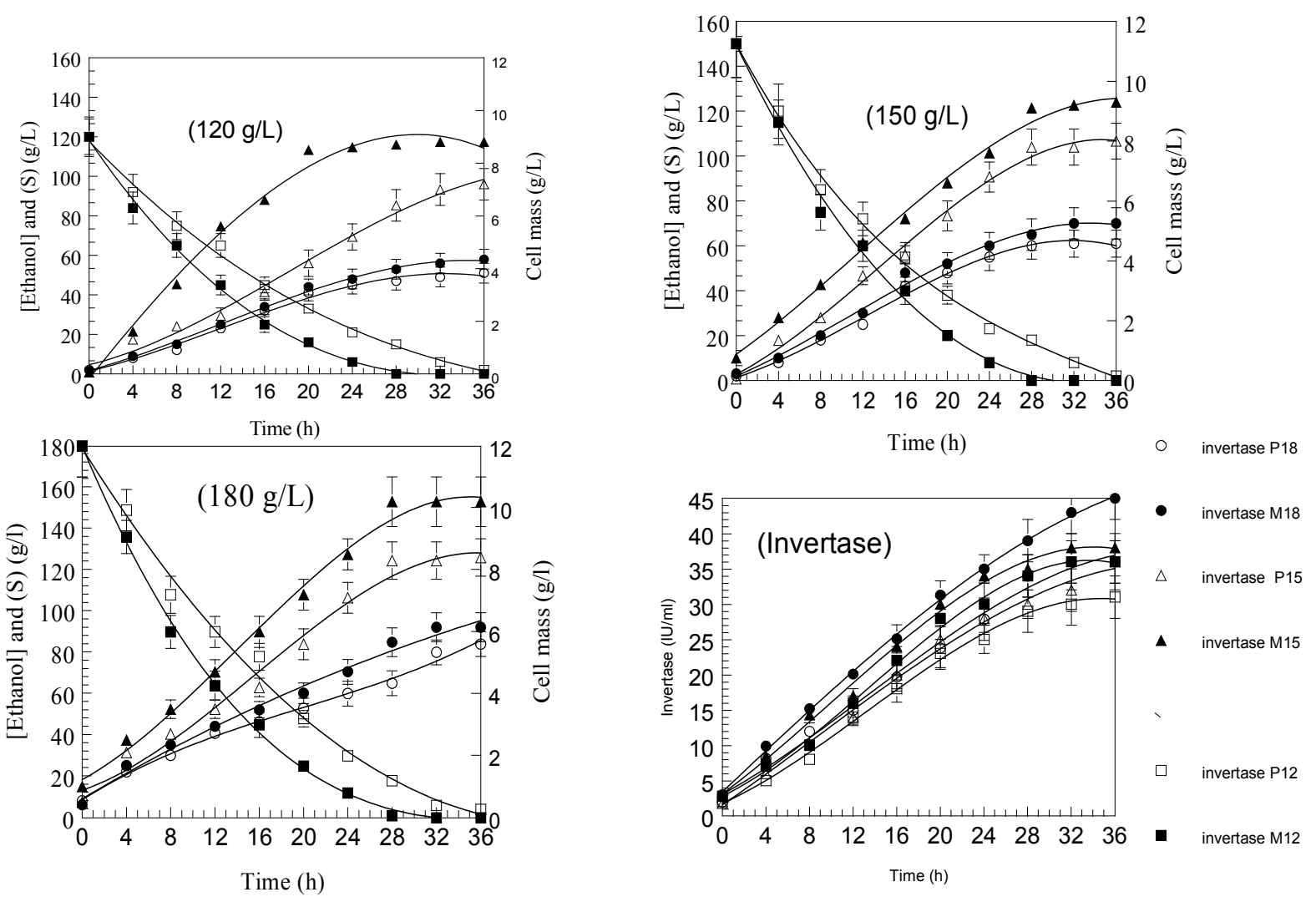

Fig. 1. Comparative depiction of fermentation kinetic parameters of S. cerevisiae (P) and its mutant for ethanol formation. 
Table 1. Comparative fermentation kinetic parameters of $S$. cerevisiae $(\mathrm{P})$ and its multiple mutant (SML-1, M) for ethanol formation (kinetic parameters following growth on molasses under optimized cultivation conditions).

\begin{tabular}{|c|c|c|c|c|c|c|}
\hline Carbon source $\left(\mathrm{L}^{-1}\right)$ & & $\begin{array}{c}\mathrm{Q}_{\mathrm{X}} \\
\left(\mathrm{g} \text { cells L} \mathrm{h}^{-1}\right)\end{array}$ & $\begin{array}{c}\mathrm{Q}_{\mathrm{S}} \\
\left(\mathrm{g} \cdot \mathrm{L}^{-1} \mathrm{~h}\right)\end{array}$ & $\begin{array}{c}\mathrm{Y}_{\mathrm{X} / \mathrm{s}} \\
\left(\mathrm{g} \cdot \mathrm{g}^{-1} \mathrm{sub} .\right)\end{array}$ & $\begin{array}{c}\mathrm{q}_{\mathrm{S}} \\
\left(\mathrm{g} \cdot \mathrm{g}^{-1} \mathrm{~h}^{-1}\right)\end{array}$ & $\begin{array}{c}\mu_{\mathrm{m}} \\
\left(\mathrm{h}^{-1}\right)\end{array}$ \\
\hline \multirow{2}{*}{$120 \mathrm{~g}$} & $\mathrm{P}$ & $0.12 \pm 0.02^{\mathrm{b}}$ & $3.5 \pm 0.2^{\mathrm{b}}$ & $0.06 \pm 0.02^{\mathrm{b}}$ & $3.83 \pm 0.2^{\mathrm{b}}$ & $0.23 \pm 0.02^{\mathrm{b}}$ \\
& $\mathrm{M}$ & $0.22 \pm 0.2^{\mathrm{a}}$ & $4.4 \pm 0.2^{\mathrm{a}}$ & $0.065 \pm 0.02^{\mathrm{a}}$ & $4.15 . \pm 0.2^{\mathrm{b}}$ & $0.27 \pm 0.02^{\mathrm{b}}$ \\
\hline \multirow{2}{*}{$150 \mathrm{~g}$} & $\mathrm{P}$ & $0.28 \pm 0.02^{\mathrm{b}}$ & $3.9 \pm 0.2^{\mathrm{b}}$ & $0.061 \pm 0.02^{\mathrm{b}}$ & $5.08 \pm 0.2^{\mathrm{a}}$ & $0.31 \pm 0.02^{\mathrm{a}}$ \\
& $\mathrm{M}$ & $0.35 \pm 0.02^{\mathrm{a}}$ & $4.6 \pm 0.2^{\mathrm{a}}$ & $0.066 \pm 0.02^{\mathrm{a}}$ & $5.15 \pm 0.2^{\mathrm{a}}$ & $0.34 \pm 0.02^{\mathrm{a}}$ \\
\hline \multirow{2}{*}{$180 \mathrm{~g}$} & $\mathrm{P}$ & $0.12 \pm 0.2^{\mathrm{b}}$ & $3.85 \pm 0.2^{\mathrm{b}}$ & $0.056 \pm 0.02^{\mathrm{b}}$ & $5.36 \pm 0.2^{\mathrm{a}}$ & $0.30 \pm 0.02^{\mathrm{a}}$ \\
& $\mathrm{M}$ & $0.25 \pm 0.2^{\mathrm{a}}$ & $4.45 \pm 0.2^{\mathrm{b}}$ & $0.060 \pm 0.02^{\mathrm{a}}$ & $5.33 \pm 0.2^{\mathrm{a}}$ & $0.32 \pm 0.02^{\mathrm{a}}$ \\
\hline
\end{tabular}

Each value is a mean $\pm \mathrm{SD}$ of three replicates; values followed by different letters in superscript in each column represent differences among carbon sources for the production of ethanol

Table 2. Comparative fermentation kinetic parameters of $S$. cerevisiae $(\mathrm{P})$ and its multiple mutant (SML-1, M) for ethanol formation (kinetic parameters following growth on $15 \%$ TFS in molasses under optimized cultivation conditions).

\begin{tabular}{|c|c|c|c|c|c|c|}
\hline Carbon source $\left(\mathrm{L}^{-1}\right)$ & & $\begin{array}{c}\mathrm{Q}_{\mathrm{p}} \\
\left(\mathrm{g} \mathrm{L}^{-1} \mathrm{~h}^{-1}\right)\end{array}$ & $\begin{array}{c}\mathrm{Y}_{\mathrm{P} / \mathrm{X}} \\
\left(\mathrm{g} \mathrm{g}^{-1} \text { cells }\right)\end{array}$ & $\begin{array}{c}\mathrm{Y}_{\mathrm{P} / \mathrm{S}} \\
\left(\mathrm{g}^{-\mathrm{g}^{-1}} \text { sub. }\right)\end{array}$ & $\begin{array}{c}\mathrm{q}_{\mathrm{p}} \\
\left(\mathrm{g} \mathrm{g}^{-1} \mathrm{~h}^{-1}\right)\end{array}$ & $\begin{array}{c}\text { Theoretical } \\
\text { yield }(\%)\end{array}$ \\
\hline \multirow{2}{*}{$120 \mathrm{~g}$} & $\mathrm{P}$ & $2.1 \pm 0.2^{\mathrm{b}}$ & $7.1 \pm 0.2^{\mathrm{b}}$ & $0.43 \pm 0.02^{\mathrm{b}}$ & $1.6 \pm 0.2^{\mathrm{b}}$ & $84 \pm 2^{\mathrm{b}}$ \\
& $\mathrm{M}$ & $2.8 \pm 0.2^{\mathrm{a}}$ & $8.7 \pm 0.2^{\mathrm{a}}$ & $0.48 \pm 0.02^{\mathrm{a}}$ & $2.8 \pm 0.2^{\mathrm{a}}$ & $93 \pm 3^{\mathrm{a}}$ \\
\hline \multirow{2}{*}{$150 \mathrm{~g}$} & $\mathrm{P}$ & $2.2 \pm 0.2^{\mathrm{b}}$ & $7.8 \pm 0.2^{\mathrm{b}}$ & $0.47 \pm 0.02^{\mathrm{b}}$ & $1.8 \pm 0.2^{\mathrm{b}}$ & $92 \pm 4^{\mathrm{a}}$ \\
& $\mathrm{M}$ & $2.9 \pm 0.2^{\mathrm{a}}$ & $9.2 \pm 0.2^{\mathrm{a}}$ & $0.48 \pm 0.02^{\mathrm{a}}$ & $2.6 \pm 0.2^{\mathrm{a}}$ & $93 \pm 3^{\mathrm{a}}$ \\
\hline \multirow{2}{*}{$180 \mathrm{~g}$} & $\mathrm{P}$ & $1.9 \pm 0.2^{\mathrm{b}}$ & $7.7 \pm 0.2^{\mathrm{b}}$ & $0.40 \pm 0.02^{\mathrm{b}}$ & $2.2 \pm 0.2^{\mathrm{b}}$ & $78 \pm 3^{\mathrm{c}}$ \\
\hline \multirow{2}{*}{$\mathrm{P}$} & $\mathrm{M}$ & $3.1 \pm 0.2^{\mathrm{a}}$ & $8.9 \pm 0.2^{\mathrm{a}}$ & $0.48 \pm 0.02^{\mathrm{a}}$ & $2.9 \pm 0.2^{\mathrm{a}}$ & $93 \pm 3^{\mathrm{a}}$ \\
\hline
\end{tabular}

Each value is a mean $\pm \mathrm{SD}$ of three replicates; values followed by different letters in superscript in each column represent difference among carbon sources for the production of ethanol

were supported at a significantly higher value $(\mathrm{P}<0.001)$ by the mutant SML-1 than the values supported by the wild organism, and were considered the factors that might control product synthesis by different concentrations of substrate. There were variations in specific growth rates and substrate uptake rates during growth on all carbon source concentrations in the case of mutant derivatives, permitting larger variation in synthesis of invertase and ethanol by this organism (Table 2, Fig. 1). Lower concentrations of carbon source in the medium supported lower growth of yeast, resulting in less yield of invertase (Fig. 1) and ethanol (Table 2).

Multiple mutations enhanced the specific ethanol yield $\left(\mathrm{Y}_{\mathrm{P} / \mathrm{X}}\right)$, product yield $\left(\mathrm{Y}_{\mathrm{P} / \mathrm{S}}\right)$, volumetric rate of ethanol formation $\left(\mathrm{Q}_{\mathrm{p}}\right)$, and specific rate of ethanol formation $\left(\mathrm{q}_{\mathrm{p}}\right)$ up to $119,120.9,142.6$, and $149 \%$ over respective values of parental strain, respectively (Table 2), while invertase productivity $(1,560 \pm 50 \mathrm{IU} / \mathrm{L} \mathrm{h})$ was $220 \%$ higher than that of the wild organism. Volumetric yields of ethanol (Table 1) were higher than those reported by other authors $(1,13,17)$. Our mutant strain showed better results than those by the wild organism on all concentrations of sugars in molasses and temperatures. These values were also higher than those exhibited by a multiple mutant strain of Kluyveromyces marxianus, which took $60 \mathrm{~h}$ to consume $150 \mathrm{~g}$ glucose/1 and commercial strain of $\mathrm{S}$. cerevisiae consumed $150 \mathrm{~g}$ glucose $/ 1$ in $48 \mathrm{~h}$ at $30-32^{\circ} \mathrm{C}$ (23), but our mutant completed industrial scale fermentation in $28 \mathrm{~h}$.

Thus multiple mutagenesis improved results of both substrate consumption (Table 1) and product formation parameters (Fig. 1, Table 2). These results suggested that the multiple mutagenesis resulted in an excellent improvement of the multi-genes-controlled characters of yeast strain for improved ethanol and invertase production. The mutant strain demonstrated a more industrious mode showing improved behavior for thermotolerance, osmotolerance, substrate consumption, and ethanol yield.

\section{Genetic Variability between the Mutant and Parent Strains}

Samples of genomic DNA of parental and mutant strains were analyzed by RAPD-PCR method. They was used to verify that the mutant isolate was genetically different from the parental organism. A total of 35 primers were employed. A total of 204 loci were amplified, with an average of $\sim 6$ loci per primer. Out of the 35 primers, 9 primers (OPA-03, OPB-01, OPB-03, OPB-05, OPE-02, OPE-05, OPK-01, OPK-03, and OPK-05) amplified polymorphic DNA fragments 
Table 3. Comparative fermentation kinetic parameters of $S$. cerevisiae $(\mathrm{P})$ and its multiple mutant (SML-1, M) for ethanol formation (kinetic parameters following growth on molasses under optimized cultivation conditions).

\begin{tabular}{|c|c|c|c|}
\hline Temperature & & $\begin{array}{c}\mathrm{Q}_{\text {pinvertase }} \\
\left(\mathrm{IU} \mathrm{L}^{-1} \mathrm{~h}^{-1}\right)\end{array}$ & $\begin{array}{c}\mathrm{Y}_{\text {P ethano/s }} \\
\left(\mathrm{gg}^{-1} .\right)\end{array}$ \\
\hline \multirow{2}{*}{27} & $\mathrm{P}$ & $615 \pm 30^{\mathrm{c}}$ & $0.42 \pm 0.03^{\mathrm{a}}$ \\
& $\mathrm{M}$ & $950 \pm 45^{\mathrm{b}}$ & $0.45 \pm 0.03^{\mathrm{a}}$ \\
\hline \multirow{2}{*}{32} & $\mathrm{P}$ & $715 \pm 30^{\mathrm{c}}$ & $0.44 \pm 0.03^{\mathrm{a}}$ \\
& $\mathrm{M}$ & $1560 \pm 50^{\mathrm{a}}$ & $0.47 \pm 0.03^{\mathrm{a}}$ \\
\hline \multirow{2}{*}{37} & $\mathrm{P}$ & $679 \pm 30^{\mathrm{c}}$ & $0,32 \pm 0.03^{\mathrm{b}}$ \\
& $\mathrm{M}$ & $1600 \pm 60^{\mathrm{a}}$ & $0.480 .03^{\mathrm{a}}$ \\
\hline \multirow{2}{*}{42} & $P$ & $460 \pm 20^{\mathrm{d}}$ & $0.25 \pm 0.03^{\mathrm{b}}$ \\
\hline$P$ & $M$ & $1530 \pm 45^{\mathrm{a}}$ & $0.45 \pm 0.03^{\mathrm{a}}$ \\
\hline \multirow{2}{*}{$P$} & & $>0.001$ & $>0.001$ \\
\hline
\end{tabular}

Each value is a mean $\pm \mathrm{SD}$ of three replicates; values followed by different letters in superscript in each column differ significantly at $P \leq 0.05$

in the mutant strain. A maximum 19 fragments were amplified with primer OPD-05 while the minimum number of fragments were amplified by OPA-02,

OPA-03, OPB-05, OPL-01, OPL-03, OPK-05, and OPD-03. The size of DNA fragments amplified varied from $0.5 \mathrm{~kb}$ to $2 \mathrm{kbOf}$ these polymorphic primers, three produced polymorphic loci in the parent strain and six primers produced polymorphic loci in the mutant strain of Saccharomyces cerevisiae. Thus the mutant strain showed a nearly uniform RAPD pattern, whereas the parental strain gave a heterogeneous amplification pattern. RAPD analysis was capable of readily differentiating between parent and mutant strain and production pattern of the tested strains. Both strains with some primers showed a correlation of genetic variability with enzyme production. Some other researchers used RAPD markers to verify genetic diversity and phenotypic correlation [24]. In this study $56 \%$ genetic similarity ( $2 \mathrm{x}$ numbers of common bands/ total bands) was calculated between original and mutant strains. It is therefore suggested that RAPD assay is sufficient to differentiate the wild and the mutant strains.

\section{Invertase Production Studies at Laboratory Scale}

For industrial-scale ethanol fermentation, Saccharomyces cerevisiae is the distinctive yeast strain universally employed by ethanol producers. Although many strains have been isolated/screened and characterized for improved growth rate and enhanced ethanol formation, a glucose repression problem during utilization of mixed carbon sources has yet to be resolved.

Invertase activity, ethanol percentage, and residual sugars were measured for both parent and mutant strains at varying concentrations of carbon source $(12,15,18 \%$, $\mathrm{w} / \mathrm{v}), \mathrm{pH}$, temperature, and dilution (Tables 1-5).
Table 4. Effect of controlled $\mathrm{pH}$ of the fermentation medium in $23 \mathrm{~L}$ fermenter on kinetic parameters of $S$. cerevisiae (W) and its mutant strain $(\mathrm{M})$ on ethanol and invertase formation using molasses medium ( $15 \%$ sugars).

\begin{tabular}{|c|c|c|c|c|}
\hline $\mathrm{pH}$ & Strain & $\begin{array}{c}\mathrm{Q}_{\mathrm{p}} \\
\left(\mathrm{g} \mathrm{L}^{-1} \mathrm{~h}^{-1}\right)\end{array}$ & $\begin{array}{c}Y_{p \text { ethanol/s }} \\
\text { (g/g subs) }\end{array}$ & $\begin{array}{l}\mathrm{Qp}_{\text {invertase }} \\
\left(\mathrm{IU} \mathrm{L^{-1 } h ^ { - 1 }}\right)\end{array}$ \\
\hline \multirow{2}{*}{$\mathrm{pH} 4.0$} & W & $2.1^{\mathrm{d}}$ & $0.36^{\mathrm{d}}$ & $859^{c}$ \\
\hline & M & $3.6^{\mathrm{a}}$ & $0.42^{\mathrm{b}}$ & $960^{\mathrm{c}}$ \\
\hline \multirow{2}{*}{$\mathrm{pH} 4.5$} & W & $2.4^{\mathrm{d}}$ & $0.41^{\mathrm{b}}$ & $950^{\mathrm{c}}$ \\
\hline & $\mathrm{M}$ & $3.2^{\mathrm{b}}$ & $0.48^{\mathrm{a}}$ & $1292^{\mathrm{a}}$ \\
\hline \multirow{2}{*}{ pH 5.0} & W & $2.3^{\mathrm{d}}$ & $0.39^{\mathrm{d}}$ & $930^{\mathrm{c}}$ \\
\hline & M & $3.2^{\mathrm{b}}$ & $0.46^{\mathrm{a}}$ & $1100^{b}$ \\
\hline \multirow{2}{*}{ pH 5.5} & W & $2.13^{\mathrm{e}}$ & $0.32^{\mathrm{e}}$ & $887^{c}$ \\
\hline & M & $3.28^{\mathrm{b}}$ & $0.44^{\mathrm{b}}$ & $1010^{b}$ \\
\hline \multirow{2}{*}{$\mathrm{pH} 6.0$} & W & $2.05^{\mathrm{e}}$ & $0.29^{f}$ & $884^{\mathrm{c}}$ \\
\hline & M & $3.15^{\mathrm{b}}$ & $0.41^{\mathrm{b}}$ & $985^{c}$ \\
\hline \multirow{2}{*}{$\mathrm{pH} 6.5$} & W & $1.90^{\mathrm{e}}$ & $0.26^{\mathrm{g}}$ & $750^{\mathrm{d}}$ \\
\hline & M & $2.90^{\mathrm{c}}$ & $0.39^{d}$ & $840^{\mathrm{c}}$ \\
\hline \multicolumn{2}{|c|}{$P$} & 0.0001 & 0.0001 & 0.0001 \\
\hline
\end{tabular}

Each value is a mean $\pm \mathrm{SD}$ of three replicates; values followed by different letters in superscript in each column differ significantly at $P \leq 0.05$

Temperature is one of the leading factors that has a serious effect on the production of invertase [29]. The invertase activity at different temperatures $27,32,37$, and $42^{\circ} \mathrm{C}$ was assessed (Table 3 ).

At $37^{\circ} \mathrm{C}$ enzyme activity was much higher in the case of the mutant as compared to that of the parent strain. Maximum production of invertase (33.8 U/ml, $Q_{P}=1,439 \pm 60 \mathrm{U} / \mathrm{lh}$ ) (Table 3) was obtained when incubation temperature was maintained at $37^{\circ} \mathrm{C}$ for the mutant and $32^{\circ} \mathrm{C}$ for the parent. At high temperatures, low enzyme secretion may be due to thermal inactivation of yeast culture [30]. Therefore, fermentation at elevated temperatures needs a thermotolerant strain. Further increase in incubation temperature resulted in marked decline in invertase production by both strains, but more severely in the parent. At $27^{\circ} \mathrm{C}$, enzyme production was low, which might be due to the fact that the temperature was not suitable for yeast growth. The invertase activity was found at maximum with in the temperature range of $34-39^{\circ} \mathrm{C}$ in parent and mutant, respectively. At higher temperatures after the optimal value, a decrease was observed and there was more decrease in the parent.

Kaur and Sharma et al.[31] obtained maximum invertase activity at initial $\mathrm{pH} 5.0$ in synthetic fermentation medium. In both strains, invertase production was enhanced up to $\mathrm{pH} 5.0$ then decreased as the variables increased. Shafiq et al. [29] reported that yeast always desires to grow at high $\mathrm{pH}$, but for the invertase secretion $\mathrm{pH}$ (4.6-5.0) was the best. The inhibitory influence of high $\mathrm{pH}$ (above 5.0), could be attributed 
Table 5. Comparative fermentation kinetic parameters of S. cerevisiae $(\mathrm{P})$ and its multiple mutant (SML-1, M) for ethanol and invertase formation kinetic parameters following growth on molasses used as 1:2 dilution and 1:1.5 dilution in an industrial-scale fermentation process.

\begin{tabular}{|c|c|c|c|c|c|}
\hline Dilution Used & Strain & $\begin{array}{l}\mathrm{Q}_{\text {Pinvertase }} \\
\left(\mathrm{IU} \mathrm{L}^{-1} \mathrm{~h}^{-1}\right)\end{array}$ & $\begin{array}{c}\mathrm{Y}_{\text {Pethanol/S }} \\
\left(\mathrm{L} \text {. Tonne }{ }^{-1}\right)\end{array}$ & $\begin{array}{l}\mathrm{Q}_{\text {pEth }} \\
(\mathrm{g} / \mathrm{L} . \mathrm{h})\end{array}$ & $\mathrm{Q}_{\mathrm{S}}(\mathrm{g} / \mathrm{L} \cdot \mathrm{h})$ \\
\hline $\begin{array}{c}1: 2 \\
(15 \% \mathrm{TFS})\end{array}$ & $\begin{array}{l}\mathrm{P} \\
\mathrm{M}\end{array}$ & $\begin{array}{l}609 \pm 30^{\mathrm{c}} \\
890 \pm 45^{\mathrm{b}}\end{array}$ & $\begin{array}{l}218 \pm 5^{\mathrm{b}} \\
232 \pm 6^{\mathrm{a}}\end{array}$ & $\begin{array}{l}1.19 \\
1.56\end{array}$ & $\begin{array}{l}7.2 *(0.40)^{* *} \\
8.2 *(0.47)^{* *}\end{array}$ \\
\hline $\begin{array}{c}1: 1.5 \\
(18 \% \text { TFS })\end{array}$ & $\begin{array}{l}\mathrm{P} \\
\mathrm{M}\end{array}$ & $\begin{array}{l}600 \pm 30^{\mathrm{c}} \\
990 \pm 50^{\mathrm{a}}\end{array}$ & $\begin{array}{l}222 \pm 8^{\mathrm{b}} \\
240 \pm 9^{\mathrm{a}}\end{array}$ & $\begin{array}{l}1.29 \\
1.67\end{array}$ & $\begin{array}{l}8.19 *(0.47)^{* *} \\
9.2 *(0.51)^{* *}\end{array}$ \\
\hline$P$ & & $>0.001$ & $>0.0214$ & & \\
\hline
\end{tabular}

Each value is a mean $\pm \mathrm{SD}$ of three crops; values followed by different letters in superscript in each column differ significantly at $P \leq 0.05$; *rate of substrate accumulation; **rate of substrate uptake

to the lower ATP formation during the metabolic changes in Saccharomyces cerevisiae. In both strains invertase production was significantly affected by $\mathrm{pH}$. Today it is necessary to move to alternate energy sources that will reduce over-dependence on non-renewable energy sources like fossil fuels. This will definitely be a cost-effective and eco-friendly approach [32-45].

\section{Conclusions}

The mutant strain completed fermentation with high efficiency in 28 hours as compared with the parent that took 36 hours for completing fermentation. The mutants obtained are of great commercial value as it has the potential to decrease the overall cost of the fermentation process and improve the quality of ethanol. The strain is characterized and optimized for invertase production at laboratory scale and has been trialed successfully at full industrial scale.

\section{Acknowledgements}

This study was financially supported by Shukkargunj Sugar Mills and the University of Agriculture, Faisalabad. Mutation studies and small-scale fermenter studies were performed at NIBGE. Some chemicals were purchased using funds made available under PCST proposal No. 6.163. M. Arshad was supported by the Higher Education Commission, government of Pakistan.

\section{Conflict of Interest}

The authors declare no conflict of interest.

\section{References}

1. SANCHEZ O.J., CARDONA C.A. Trends in biotechnological production of fuel ethanol from different feed stocks.Bioresour Technol. 99, 5270, 2008.
2. BOSAK M., HAJDUOVA Z., MAJERNIK M., ANDREJOVSKY P. Experimental-Energy Combustion of Biomass Combined with Coal in Thermal Power Plants. Pol. J. Environ. Stud. 24 (4), 1517, 2015.

3. KHAIRUDDIN N., MUNAF L.A., HASSAN M.A., HALIMOON N., AZLINA W., KARIM W.A. Biogas Harvesting from Organic Fraction of Municipal Solid Waste as a Renewable Energy Resource in Malaysia: A Review. Pol. J. Environ. Stud. 24 (4), 1477, 2015.

4. WOCH F., HERNIK J., WYROZUMSKA P., CZESAK B. Residual Woody Waste Biomass as an Energy Source Case Study. Pol. J. Environ. Stud. 24 (1), 355, 2015.

5. WU R., ZHANG J., BAO Y., TONG S. Using a Geographically Weighted Regression Model to Explore the Influencing Factors of $\mathrm{CO}_{2}$ Emissions from Energy Consumption in the Industrial Sector. Pol. J. Environ. Stud. 25 (6), 2641, 2016.

6. KASIULIENE A., PAULAUSKAS V., KUMPIENE J. Chelant-Assisted Accumulation of $\mathrm{Cd}, \mathrm{Cu}$, and $\mathrm{Zn}$ in Rapeseed (Brassica napus L.) Biomass as a Renewable Energy Feedstock. Pol. J. Environ. Stud. 25 (5), 1985, 2016.

7. KHAIRUDDIN N., MUNAF L.A., HASSAN M.A., HALIMOON N., AZLINA W., GHANI A.K. High Solid Anaerobic Co-Digestion of Household Organic Waste with Cow Manure for Mass and Energy Recovery. Pol. J. Environ. Stud. 25 (4), 1549, 2016.

8. QAIO Y., MIAO S., YUE S., WU H., HAN X. How 23-year Continuous Soybean Cultivation Led to More SOC and Thermal Energy Stored in Mollisol Micro-Aggregates. Pol. J. Environ. Stud. 25 (3), 1215, 2016.

9. RYBICKI S.M. Role of Primary Sludge Hydrolysis in Energy Recovery from Municipal Wastewater Sludge. Pol. J. Environ. Stud. 23 (3), 1033, 2014.

10. BRODZINSKI Z., KRYSZK H., KUROWSKA K. Market of Producers and Processors of Agricultural Biomass for Energy Purposes. Pol. J. Environ. Stud. 23 (2), 619, 2014.

11. STOLARSKI M.J., KRZYZANIAK M., SZCZKOWSKI S., TWORKOSKI J., BIENIEK A. Dendromass Derived from Agricultural Land as Energy Feedstock. Pol. J. Environ. Stud. 22 (2), 511, 2013.

12. PETERS D. Carbohydrates for fermentation.Biotechnol J. 1, 806, 2006.

13. RINCON A.M., CODON A.C., CASTREJON F., BENITEZ T. Improved properties of baker's yeast mutants resistant to 2-deoxy-d-glucose. Appl Environ Microbiol. 67, 4279, 2001.

14. OLSSON L., NIELSEN J. The role of metabolic engineering in the improvement of Saccharomyces 
cerevisiae: utilization of industrial media. Enzyme and Microbial Technol. 26, 785, 2000.

15. TSOLMONBAATAR A., HASHIDA K., SUGIMOTO Y., WATANABE D., FURUKAWA S., TAKAGI H. Isolation of baker's yeast mutants with proline accumulation that showed enhanced tolerance to baking-associated stresses. Int J Food Microbiol. 238, 233, 2016.

16. RINCÓN A.M., CODÓN A.C., CASTREJÓN F., BENÍTEZ T. Improved Properties of Baker's Yeast Mutants Resistant to 2-Deoxy-D-Glucose. Appl Environ Microbiol. 67 (9), 4279, 2001. Repetition!

17. TAKESHIGE K., OUCHI K. Effects of yeast invertase on ethanol production in molasses.J FermenBioeng. 79, 513$515, \mathbf{1 9 9 5}$.

18. PRESCOTT S., DUNN'S A. Industrial Microbiology. $4^{\text {th }}$ edition, CBS Publishers and Distributors, New Dehli, India; 2002.

19. CONVERTI A., ARNI S., SATO S., DE CARVALHO J.C.M., AQUARONE E. Simplified modeling of fed-batch alcoholic fermentation of sugarcane blackstrapmolasses. BiotechnolBioeng. 84, 88, 2003.

20. SRIDHAR V., ELLIOTT R.L. On the development of a simple down welling long wave radiation scheme. Agric Forest Meteorol. 112, 237, 2002.

21. RAJOKA M.I., FERHAN M., KHALID A.M.Kinetics and thermodynamics of ethanol production by a thermotolerant mutant of Saccharomyces cerevisiae in a microprocessorcontrolled bioreactor. LettApplMicrobiol. 40, 316, 2005.

22. ARSHAD M., KHAN Z.M., REHMAN K., SHAH F.A., RAJOKA M.I. Optimization of process variables for minimization of byproducts formation during fermentation of blackstrap molasses to ethanol at industrial scale. LettApplMicrobiol. 47, 410, 2008.

23. REEVES M. Kinetic analysis of Kluyveromycesmarxianus yeast strain. M.Sc. Thesis. Department Bio. Agri. Eng. B. S., Louisiana State University; 2001.

24. ZHANG Y., MOQTADERI Z., RATTNER B.P., et al. Intrinsic histone-DNA interactions are not the major determinant of nucleosome positions in vivo. Nat StructMol Bio. 16, 847, 2009.

25. HAQ I., SHAFIQ K., ALI S. Kinetics of phosphate ions induced invertase synthesis by Saccharomyces cerevisiae. Int J Agri Bio. 6, 363, 2004.

26. BAIG M.A., SHAFIQ K., MIRZA S., ALI S., IKRAM-UL-HAQ. Effect of urea as an inducer of $\beta$-fructofuranosidase in Saccharomyces fermentation. Pak J Nutrition. 2, 106, 2003.

27. EGOROV S.N., SEMENOVA I.N., MAKSIMOV V.N. Mutual effect of invertase and acid phosphatase from the yeast Saccharomyces cerevisiae on their secretion into culture media. Mikrobiologiia. 69, 34, 2000.

28. GOMEZ-LORENZO M.G., SPAHN C.M., AGRAWAL R.K., ET AL. hree-dimensional cryo-electron microscopy localization of EF2 in the Saccharomyces cerevisiae 80S ribosome at 17.5 A resolution. EMBO J. 19, 2710, 2000.

29. SHAFIQ K., ALI S., IKRAM-UL-HAQ. Temperature optima for invertase secretion by yeast in synthetic medium. Pak J Life Soc Sci. 2, 21, 2004.

30. MIZUNAGA T., IKACZ J.S., RODRIGUEZ L., HACKEL R.A., LAMPEN J.O. Temperature-sensitive forms of large and small invertase in a mutant derived from a Suc1 strain of Saccharomyces cerevisiae. Mol Cell Biol. 1, 460, 1981.

31. KAUR N., SHARMA A.D. Production, optimization and characterization of extracellular invertase by an actinomycetes strain. J SciInd Res. 64, 515, 2005.

32. SZALATKIEWICZ J. Energy Recovery from Waste of Printed Circuit Boards in Plasmatron Plasma Reactor. Pol. J. Environ. Stud. 23 (1), 277, 2014.

33. ZHANG F, CAO G. Resilience of Energy and $\mathrm{CO}_{2}$ Exchange to a Summer Heatwave in an Alpine Humid Grassland on the Qinghai-Tibetan Plateau. Pol. J. Environ. Stud. 26 (1), 385, 2017.

34. LI W., ZHANG H. Decomposition Analysis of Energy Efficiency in China's Beijing-Tianjin-Hebei Region. Pol. J. Environ. Stud. 26 (1), 189-203, 2017.

35. BIERANOWSKI J., OLKOWSKI T. The Concept of an Energy Self-Sufficient Farm System Compatible with Sustainable Development in a Selected Region in Poland. Pol. J. Environ. Stud. 25 (2), 529, 2016.

36. CARNOGURSKA M., PRIHODA M., ZELENAKOVA M., LAZAR M., BRESTOVIC T. Modeling the Profit from Hydropower Plant Energy Generation Using Dimensional Analysis. Pol. J. Environ. Stud. 25 (1), 73, 2016.

37. STOLARSKI M.J., KRZYZANIAK M., WARMINSKI K., TWORKOSKI J., SZCZKOWSKI S. Willow Biomass Energy Generation Efficiency and Greenhouse Gas Reduction Potential. Pol. J. Environ. Stud. 24 (6), 2627, 2015.

38. WEN L., CAO Y., WENG J. Factor Decomposition Analysis of China's Energy-Related $\mathrm{CO}_{2}$ Emissions Using Extended STIRPAT Model Pol. J. Environ. Stud. 24 (5), 2261, 2015.

39. MAJ G. Diversification and Environmental Impact Assessment of Plant Biomass Energy Use. Pol. J. Environ. Stud. 24 (5), 2055, 2015.

40. SHEN N., ZHOU J., ZOU W. Energy Efficiency Measures and Convergence in China, Taking into Account the Effects of Environmental and Random Factors. Pol. J. Environ. Stud. 24 (1), 257, 2015.

41. KWASNIEWSKI J., DOMINIK I., KSZUBA F. Energy Harvesting System Based on Ionic Polymer-Metal Composites - Identification of Electrical Parameters. Pol. J. Environ. Stud. 23 (6), 2339, 2014.

42. GUMULA S., PYTEL K., PIASKOWSKA-SILARSKA M. Environmental and Economic Benefits of Using Kinetic Wind Energy to Generate Electricity. Pol. J. Environ. Stud. 23 (6), 2315, 2014.

43. STOLARSKI M.J., KRZYZANIAK M., SZCZKOWSKI S., TWORKOSKI J., BIENIEK A. Short Rotation Woody Crops Grown on Marginal Soil for Biomass Energy. Pol. J. Environ. Stud. 23 (5), 1727, 2014.

44. WOCH F., HERNIK J., WIKLINA U., TOLAKA M. Energy Autarky of Rural Municipality Created on the Basis of Renewable Energy Resources. Pol. J. Environ. Stud. 23 (4), 1441, 2014.

45. GULA A., GORYL W. Toward a More Environmentally Friendly Use of Biomass for Energy Purposes in Poland. Pol. J. Environ. Stud. 23 (4), 1377, 2014. 
